\title{
Functional Effectiveness of New Budget Instruments in the Euro Area and Possible Deviations in EU's Fiscal Policies
}

\author{
Ahmet Niyazi Özker \\ Assoc. Prof. Dr., Public Finance Department, Faculty of Economic and Business Administration, Bandirma \\ Onyedi Eylul University - $10200 \backslash$ TURKEY
}

\begin{abstract}
The Euro Area within the European Union tend to put a significant budget-based process of implementation with its significant alteration structural as well as the economic and financial effects in the concerned harmonization process. In this study, we aimed to reveal and analyse these possible effects in two important stages. The first of these is to introduce new budget functions in practice and to understand and analyse the impact level of these structural functions as categorical application flow. This is because the borrowing and financial supporting need of some countries in the Eurozone have different effects on the basis of the EU budget and have raised important debates. The second one is to understand the possible effects of the possible financial changes expected by the EU in the Euro Area. Besides, the some financial and economic problems related to the harmonization process have tried to force some new member countries to change radically of their public budgets for a long time, which means to aim a financial stabilization function. This phenomenon emphasizes, including reform support schemes, that the functional position of the intended investment programs be explained by budget-based policies. This approach in the study aims to set forth the main aim of this study concerning some issues of monetary union in the national reform priorities practicing.
\end{abstract}

Keywords: Budget-Based Policies, Budget Instruments, Euro Area, EU Budget, GNP.

JEL Codes: F16, F45, P41, P48.

DOI: $10.7176 / \mathrm{JESD} / 10-16-06$

Publication date: August $31^{\text {st }} 2019$

\section{Introduction}

The Euro Area, which is the subject of important implementations within the scope of the European Union (EU), faces significant structural problems in establishing a common EU budget, which aim to generalize its common currency use. Firstly, significant financial support for the use of the common currency is undoubtedly need a common EU budget, and this approach significantly differentiates the financial functional structure of the EU budget targeted within the EU. This difference arises from the fact that the expectations for the future of the EU go into a different period and that the EU revisits some of its financial strategies for the future. This phenomenon has undoubtedly has changed the structural priorities of budget-based resource utilization in the recently years. In this context, the new budget for the future has to formulate important support policies on the priority of the financial institutions and it can be said that this current reality is guide to the selection of financial resources especially in the formation of joint investment budgets.

Therefore, creating a meaningful-effective budget within the EU, especially for Eurozone as a priority, has become a result of increasing budgetary functions and an increasing need for funds on a budget basis. From this point of view, within the scope of the EU, we see that budget-supported funds are more focused on researchdevelopment and innovation for future investments rather than realizing existing investment projects, especially on the basis of investments (European Commission, 2017: 4). Recent studies on the financial agenda of the EU regarding the functional structure of the budget, which is aimed to be established in relation to a common EU budget, have frequently brought this approach to the agenda. The official study that is very meaningful of these studies is the European Commission's own work (2018). Although the current problems of common currency use are emphasized in this study, we see that the new functional structure of a common EU budget is emphasized in the solution of the problems. In addition, we see that a modern participatory EU budget is aimed at creating a multi-year future budget emphasizing the new functional dynamics for each year's applications.

This approach has put forth that the current position of the budget functions in the Eurozone can be considered as three main structural budget functions. In the other words, this functional approach can be defined as defined as the regional character of EU harmonization policies. It should also be emphasized that another study by the European Commission (2018) on the issue. This study is quite meaningful because of that put forth the determinations of why a common budget function is needed to achieve a monetary union on an economic basis. Besides, the another study of Dias et al (2019) that has been realised by the support of the European Parliament, which emphasizes the dynamics and balances of public finance targeted for a common EU budget, is very important for the new EU member states. In this study, these researchers, specifically emphasized the position of a new common budget direct to include the functional dynamics, which brings up a functional competitive support policy. In particular, this study is important due to emphasize the linking of public spending limits of new EU 
member states with EU standards and the negative impact of possible budget deficits on the functional effectiveness of a common EU budget (Downes et al, 2017: 22). In this study of Downes, we also see that also emphasized the application proposals for new budget functions and the priority dynamics of structural budget change in the possible financial crises (Downes et al, 2017: 26).

\section{The Structural Formation of New Budget Instruments and Systemic Reform Priorities in Application}

In terms of Eurozone, a structural budget balance has been made obligatory for the establishment of joint financial contribution funds and for the harmonization of these funds with regional investment targets. This necessity first raises the necessity of the new budget instruments that we consider to include national reforms and this fact makes the national reform programs a priority in itself. In other words, effective new budget instruments for the Euro Area constitute the current dynamics of reform programs (OECD, 2018: 3). It is important that the intended infrastructure of a balanced common monetary policy needs these common funds. In this respect, the conditions of the recent Euro Area full member countries are considered as an important condition for the welfare level of the country concerned. At this point, structural failures in achieving a stable common monetary union for the EU can be said to be due to the inadequacy of reform support programs (European Parliament, 2010: 11).

\subsection{Institutional Perspective and Budget Implementation Objectives in Euro Area}

For the Euro Area, establishing an institutional perspective in budgetary practices and carrying out financial objectives through institutional support policies is important for the structural legitimacy of the levels of financial contribution to the budget. A meaningful budget with a common currency, which is expected to be effective in EU applications, raises various problems in terms of financial functions unless it presents an institutional identity and perspective for Eurozone. It is possible to gather all of these phenomena, which would make the investment and reform targets clearer on national platforms, within the framework of an institutional perspective (Vooren, 2010: 6-7). In other words, the fact that macro approaches such as energy policies, transnational transport and security policies, which can be handled as EU policies at the macro level, are functionally depend on the balanced distribution of investments in the Euro Area requires institutional guidance. Therefore, it is rather important inevitably the effective institutional implementation such as the European Parliament decision process that include the European Financial Board to provide a common budget in Euro Area.

In this context, it is possible to summarize some of the reform targets connected with the common Euro Budget to that can be addressed on an institutional basis in the Euro Area as follows (Dias et al, 2019: 2).

- Structural Reforms based on the Institutional Basis: Selection of budget-based financial instruments to ensure the effective structure of all manufacturing and service providers, including labour markets related to functional budgetary practices (Isaac et al, 2015: 2).

- Euro Area Financial Policies and Their Institutional Compliance: Ensuring institutional effectiveness for the effectiveness of a common currency in Euro Area to ensure the structural effectiveness of institutional support and compliance supported by budgetary financial instruments within the framework of these policies (Dias et al, 2019: 10).

- Corporate Cohesion of the Financial Sector and the Banks Association Objectives: To ensure the harmonization of common monetary policies, this is one of the most important problems in the Euro Area, on the basis of institutions. Strengthening the Euro, especially through the institutional co-operation of European Banks on the basis of a common European Banking (Alexander, 2010:3).

- Structural-Institutional Deepening of the Economic and Monetary Union (EMU): Increasing the institutional implementation and effectiveness of EMU on the basis of all member states. Providing a common monetary value measure in bank applications and ensuring the harmonization and effectiveness of financial applications and audits, which have become more rooted in increasing institutional, with functional budget instruments (Wescott, 2008: 44).

Within the framework of the institutional perspective, the effectiveness of the EU budget discussed above depends undoubtedly on the institutional functional effectiveness of the expenditures related to the budget. This approach based on EU budget expenditures has reached an important dimension with the common agricultural and environmental policies regarding the institutional nature of the EU budget as well as economic and social policies (Ferrera, 2018: 29). In particular, the expenditures in the structural reforms mentioned above and the establishment of institutional rooted structures for common currency applications are important in this respect. In terms of EU policies, all institutional supports are a view of functional efficiency classifications in terms of EU budget. In Figure 1 below, it is possible to see the increase rates of increases for institutional level budget implementations. 


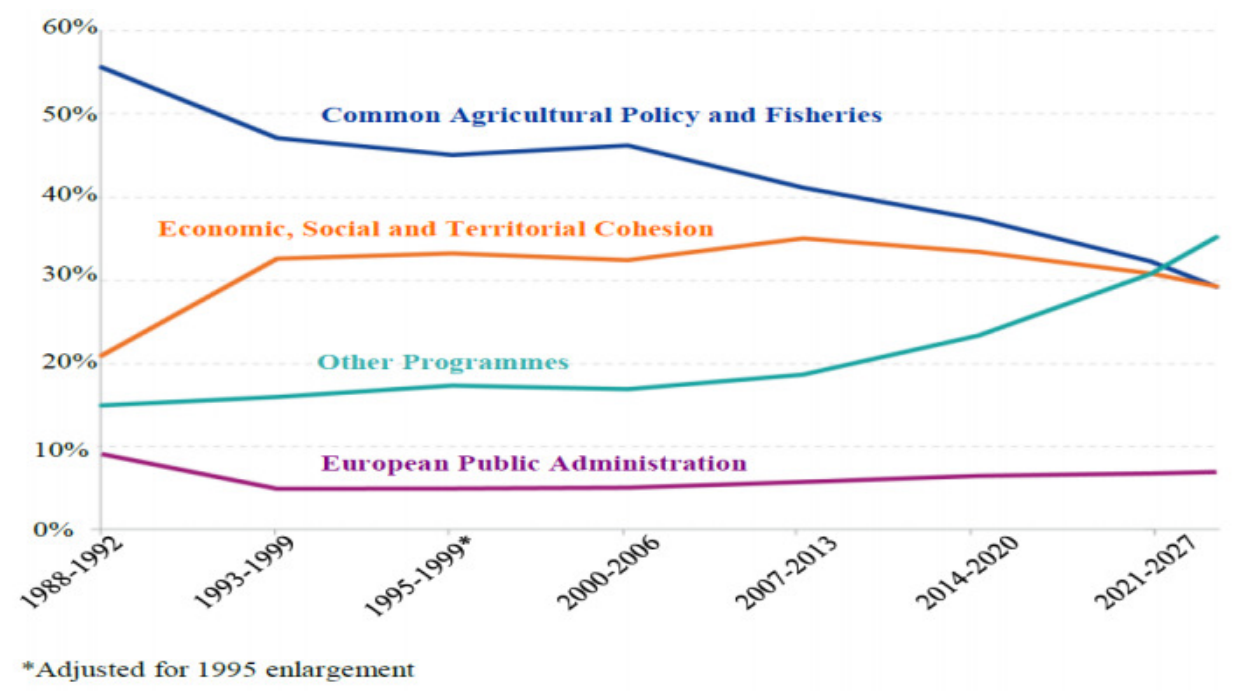

Source: European Commission (2019), Post-2020 MFF Orientations for Cohesion Policy, Brussels: European Commission Directorate, 2019, p. 4.

Figure 1. The Evolution of Institutional Expenditures Policy in EU Budget Area

As seen in Figure 1, it is observed that there was no significant change in the common agricultural and socialeconomic programs, and even in the post-2014 years, when proportional decreases took periods, but there has been an increasing in the other programmes. In the scope of the other policies, it is significant to increase the expenditure rates especially for the harmonization of financial institutions of member countries. Efforts to achieve this have resulted in an increase of approximately twice the expenditure. However, it should be also emphasized that contributory aid from a common budget to some new member countries has a significant share in these increase rates. However, a significant proportional increase in other programs cannot be denied as a result of the said costs of non-compliant institutional structures related to the new within the EU.

These brief approaches, which we refer to as an institutional perspective, also reveal the spending limits for the EU budget for the Euro Area. In this context, we can talk about two main approaches which are the subject of discussion about increasing institutional effectiveness in EU budget-based applications (Downes et al, 2017: 4). The first of these discussions relates to which institutional measures will be taken to identify spending priorities and increase the effectiveness of common EU budget-based expenditures (Druel et al, 2015: 19-20). The second discussion of the institutional framework for budgetary activity in the Euro Area concerns how the institutional content of dynamic wage policies and tax practices should be in implementing structural reforms. In particular, the applications of the financial sector on the basis of banks are directly related to wage and production policies in the relevant countries. This fact, which is the subject of discussion, also cause in the emergence of significant costs for the EU budget and the burden on behalf of the member states. This phenomenon that needs to be overcome at the institutional level leads to the discussion of the effectiveness of functional budget instruments in developing budget expenditure functions and providing fiscal balance policies (Schick, 2003: 17). At this stage, financial balance policies for Euro Area are tried to be provided by the automatic stabilizer effect of budgetary financial instruments and they bring often to the agenda financially effective implementation tools related to the functional effectiveness of budgetary instruments.

\subsection{The Current of Budget Instruments and the Fiscal Operational Flow Relationship for Euro Area}

As directed to a common $\mathrm{AB}$ budget the flow process of fiscal operations is in the scope of the set of transactions related to the reform support programme. Because, the harmonization of social values is as important as the harmonization of corporate financial values in order to achieve economic and monetary union. In this context, it is aimed to provide a regional balanced investment function in providing a common EU investment budget. Therefore, it can be said that financial contribution values as well as regional borrowings have a holistic meaning in terms of the flow process of financial transactions. These relations represent, without a doubt, the basis of regional energy policies and the common priorities of the Continental Europe transport operations as well as common budgetary policies for defence and regional security. In Figure 2 below, it can be seen the financial transaction integrity and its functional relationship of the new current budget instruments under the EU as aimed at the common budget and financial policies. 


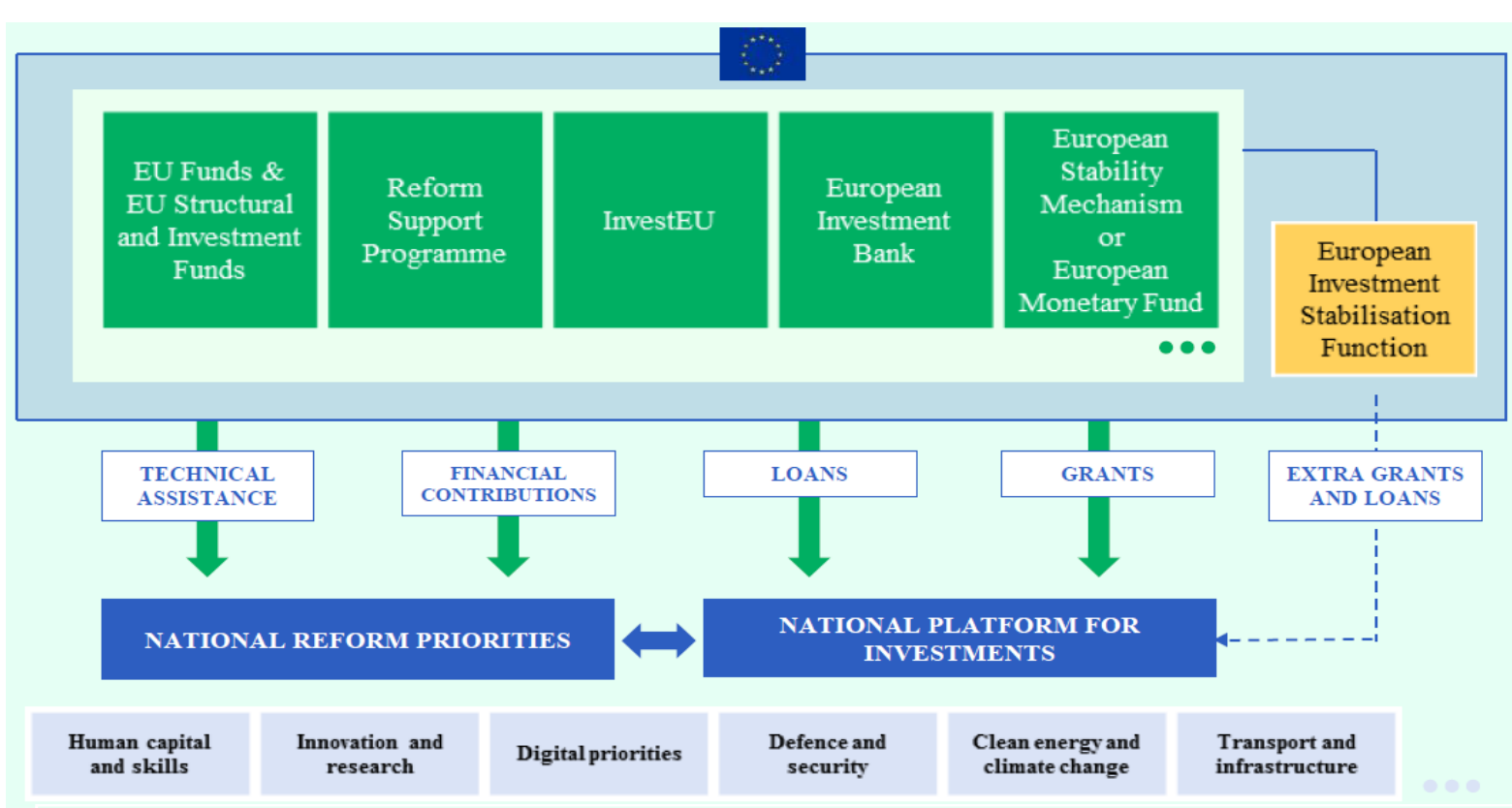

Source: European Commission (2018), EU Budget for The Future, SWD (2018) 171, Brussels: European Commission Directorate, 2.5.2018, COM (2018), p. 11.

\section{Figure 2. Relationship between Current Budget Instruments and Structural Financial Transactions in}

\section{Eurozone}

As can be seen in Figure 2, it can be said that the primary objective in establishing a common monetary support and investment union within the EU is to ensure a sound financial fund flow in the Euro Area. Of course, at this stage, it is necessary to emphasize differently the budgetary practices related to functional efficiency under the EU by differentiating it from other classical structural budget processes due to the differenced functional aims including into which practices in the implementations process. As we have already mentioned, the creation of a common EU budget within the EU is the appearance of a functional budget approach, with priority being given to support and reform programs. The process in which the European Investment Bank priority programs are included in the budget covers the functional activities where the EU investment funds have a significant place. However, the structure of these investment budgets, which also receive support from non-EU funds, also differentiates the functions related to the budget efficiency in the Eurozone region (Barbier-Gauchard et al, 2014: 65). In this respect, an investment budget created under the name of the European Monetary Fund is using four functional budget instruments in the implementation process in which a monetary balance mechanism is aimed.

These four functional approaches, which are aimed to achieve an effective structure in the budget process, serve also as an important financial resource flowing instrument for EU member states to realize their national reform priorities. In the brief, it is possible to take into consideration these functional resource transition mechanisms regarding the budget implementation process as "Technological Supports to Provide Financial Infrastructure", "External Financial Contributions", "Debt Transactions" and "Financial Appropriations" ((HM Treasury, 2018: 42; European Commission, 2018: 11). At this point, in order to overcome the problems of adaptation and integration taking into account the national priorities of EU countries, the current budget instruments are included in the process as functional budget application dynamics that express the infrastructure of financial resource formation. Besides, it should be emphasized this process are often supported via additional grants and borrowings, and this functional budget formation with its sub-dynamics that keep to increase needs more financial funds by day.

Therefore, in addition to human capital and business qualifications supported by budgetary funds, current priorities related to research and development activities, common defence and energy policies supported by Euro Area funds, and financial support from joint funds for the elimination of transportation and transportation problems, reveals the target effectiveness of financial budget functions of the current EU budget. Along with this, the harmonization of financial transactions with the sectoral and annual regional plan targets for a common EU budget is aimed at providing an important budget infrastructure. Identifying and financing the regional priority investments in achieving a common EU development trend has accelerated the flow of resources from borrowable funds as well as common financial contribution limits. At this stage, it is seen that financial instruments today often require more additional appropriations to accelerate the allocation of financial resources for the EU budget (HM Treasury, 2018: 37).

In other words, it is aimed to strengthen on the program-budget link in the EU budget with the effectiveness 
of the new budget instruments via the concerned added grants. At this point, it can be said that the effectiveness of the functions related to the current budget financial dynamics for the Euro Area is measured by the provision of an integrated financial management information system (HM Treasury, 2018: 50). In this respect, especially in the financing of EU investment projects, the determination of limits taking measures for the provision of appropriate sources such as internal Source, External Credits and Grants comes to a significant position with these functional effectiveness of the financial instruments. These whole approaches of structural finance dynamics ensure the financial informatics related a common budget intermediaries of a common budget intended for the Euro Area (HM Treasury, 2018: 54).

\section{The Functional Effectiveness Deviations in Financial Budget Rules of Euro Area in The Last Period}

In recent years, higher structural alignment and integration targets in the Euro Area have brought about significant deviations in terms of budget and fiscal policies addressed within the EU. The practices aimed at overcoming these deviations have undoubtedly made the rules established within the framework of Maastricht criteria more prominent especially in recent years and have to be meticulously addressed especially on the basis of new countries. What we should emphasize here is that these deviations should not be expressed solely by financial economic budget balances. In this context, deviations from the functional budget activity in the Euro Area as a supranational EU budget are generally seen in two main positions. The first of these is the structural deviations that arise as a result of deviations from the financial rules regarding the application of Maastricht criteria on the basis of member nation states (Council of The European Union, 2017: 7). This phenomenon has increased the current percentage of implementation of the Maastricht criteria as national complete rules in the prevention of problems that may arise from possible structural adjustment policies. Secondly, it can be stated that the deviation of EU budget expenditures and especially investment expenditures from economic functional targets against social policies.

\subsection{The Structural Impacts related to Deviations, and Location of Euro Area Functional Budget Disciplines}

Fiscal policies in EU, including Euro Area budgetary policies, are carried out as a supranational EU policy, but also include a process involving national policies. These practices and results, in which the Maastricht criteria, which are directly related to a common EU budget, are regarded as the basis, outline these rules (Mortensen, 2013: 6). For example, it is an important rule of the Maastricht Treaty that the debt limits of the member states cannot exceed 60 percent of GDP or that inflation rates should be around 3 percent on average. In this respect, the effectiveness of the common budget functions plays an important role in achieving structural adjustment in the Euro Area, and at the level of the countries in the Euro Area, the budgetary functions are set forth in supranational compact finance integrity. Adherence to these supranational fiscal rules is governed by this concerned "Stability and Growth Pact", and deviations in the effectiveness of a transnational EU budgetary function are the result of these underlying considerations and it's evaluated in this framework (Heipertz and Verdun, 2010: 1). At this stage, the financial management and implementation framework in the Euro Area has a decisive key importance in achieving structural balances and this fact has brought about a structural filtering function regarding these fiscal discipline rules in order to ensure the functional EU budget effectiveness.

On the other hand, the aim is to provide a timely equivalent package of measures to prevent possible deviations from the effectiveness of budgetary financial instruments and to create a financial auto-stabilizing effect for the automatic correction of possible changes in budget balances and financial instruments. Especially in the recent years it is seen that there are some important inevitable deviations in providing functional budget effectiveness for Euro Area due to ignore the concerned fiscal discipline rules ((Heipertz and Verdun, 2010: 1516). It can be said that these deviations mainly stem from the implementation rules of the EU budget which will increase the effectiveness of the functional budget instruments (Broin, 2012: 7-8). In another aspect, it appears that the deviations from these rules are due to the contradictions between the objectives and fiscal discipline rules of the national budgets of the member states and the objectives and rules of a common EU budget in the Euro Area. Under Euro Area Budget application in the Economic and Monetary Union (EMU), it is possible to see on the Table 1, the financial discipline mechanism that enhance the supranational financial budget functions within EU in order to prevent the concerned functional deviations below: 
Table 1. Mechanism for Fiscal Discipline directed to Budget Effectiveness in EMU

\begin{tabular}{|c|c|c|}
\hline & Rule-based governance framework & Market discipline \\
\hline \multirow[t]{2}{*}{ European level } & $\begin{array}{l}\text { Fiscal rules of the Stability and Growth Pact: nominal deficit and debt } \\
\text { limits, MTOs, expenditure benchmark and debt rule }\end{array}$ & $\begin{array}{l}\text { No-bailout clause: Article } 125 \text { of the Treaty on } \\
\text { the Functioning of the European Union }\end{array}$ \\
\hline & $\begin{array}{l}\text { Fiscal surveillance under the Stability and Growth Pact: the preventive } \\
\text { arm and corrective arm (excessive deficit procedure) of the Pact } \\
\text { administered in the European Semester by the European Commission and } \\
\text { the ECOFIN Council } \\
\text { Possible impediment to effectiveness: effective enforcementho } \\
\text { sanctioning mechanisms }\end{array}$ & $\begin{array}{l}\text { Possible impediment to effectiveness: } \\
\text { potential need for intergovernmental support to } \\
\text { ensure smooth functioning of EMU in times of } \\
\text { crisis }\end{array}$ \\
\hline \multirow[t]{3}{*}{ Member State level } & $\begin{array}{l}\text { Fiscal compact rules: balanced budget rule, benchmark for government } \\
\text { debt reduction }\end{array}$ & $\begin{array}{l}\text { Open capital market: free movement of capital is } \\
\text { one of the key elements in the EU Single Market }\end{array}$ \\
\hline & $\begin{array}{l}\text { Surveillance under the fiscal compact: monitoring of compliance with } \\
\text { rules, endorsement of budgetary and economic projections by national }\end{array}$ & $\begin{array}{l}\text { Information on government finance statistics: } \\
\text { Eurostat reporting obligations }\end{array}$ \\
\hline & $\begin{array}{l}\text { fiscal councils } \\
\text { Possible impediment to effectiveness: lack of political ownership, } \\
\text { effective enforcement/sanctioning mechanisms lacking in some cases }\end{array}$ & $\begin{array}{l}\text { Possible impediment to effectiveness: lack of } \\
\text { comparable and coherent data collection or } \\
\text { provision }\end{array}$ \\
\hline
\end{tabular}

Source: European Central Bank (2019-a), Fiscal Rules in the Euro Area and Lessons from Other Monetary Union, https://www.ecb.europa.eu/pub/economic-bulletin/articles/2019/html/ecb.ebart201903 02 $\sim$ e835720b96.en.html\#toc1(Accessed 19.07.2019).

As seen on Table 1, the negative structural effects resulting from the possible financial deviations due to the decrease in the functional efficiency of financial instruments arise due to external reasons arising from budget management-based and market discipline. This approach can be also defined as the contradictions between free market capital formation trends and the tight fiscal rules in the Euro Area. Therefore, at this stage, it is seen that a fiscal discipline process regarding the EU budget has to be dealt with on two different grounds between the "European Economic Objectives Level" and the "Member States' Goals Levels". In this position objective is to prevent the structural effects of budget-based financial deviations and to ensure that a common EU budget is controlled and disciplined by effective financial rules in the Euro Area (Dang et al, 2001: 11-12). However, it is observed that especially the deviations related to the functional budget activity are also predominantly at this point. In other words, it appears that the loss of efficiency caused by significant deviations in the functional effectiveness of the financial instruments related to the EU budget distort the structural balance of the countries in the Euro Area due to the negative impact on the common economic-financial plane. In order to ensure fiscal discipline for the $\mathrm{EU}$, it is seen that a common supranational budget is aimed especially at providing market discipline as well as a common discipline on the basis of markets and fiscal discipline rules.

In this context, in order to achieve market discipline, it is understood that sanctions aiming to remove the obstacles in the provision of sectoral balances in the market and non-salvage financial aid come to the fore. Certainly, it is aimed to prevent these deviations through the open market transactions on the basis of the member states. When this phenomenon related to deviations is approached within the framework of budget-based rules for the prevention of financial deviations, it is observed that the EU primarily targets economic growth and financial balances trend. Budgetary rules on financial deviations have aimed, increasing participation on the basis of member states, and disciplining budget financial discipline on the basis of debt policies in particular for recently years. At this stage, it is possible to say that the deviations from the member countries regarding the functional effectiveness of the budget and the transnational budget policy implemented in the Euro Area have arisen from the financial functions of budget balance with debt policies (Fabbrini, 2019: 8).

\subsection{The Aggregate Government Debt Levels and The Deviations from Structural Balances in Euro Area}

It is understood that fluctuations related to significant structural deviations at the level of the member states in terms of the EU budget have arisen especially at the debt level. In the Euro Area, this distribution is seen to be heterogeneous both in terms of countries and years. This approach has broadened the debt range of the member states in the Euro Area, especially with the increasing borrowing policies for the new member EU countries. The increases in the debt limits for the countries have stemmed from the financial infrastructures of the new 11 countries which are outside the financial integrity.

On the other hand, this negative financial phenomenon can be said to be caused by infrastructure mismatches, 
which also arise from the minimum borders of these countries. While this put forth that the debt limits and other financial deviations in the Euro Area will increase further, this financial trend has further intensified the control of budget deficits in a more controlled financial compact in the Euro Area in relation to EU budgetary practices.

However, despite the increased financial effectiveness of controlled financial policies and budgetary financial instruments in the Euro Area, the existence of budget deficits that is even if it can be controlled remains. The major reason for these deviations can be said to be due to structural mismatches as a result of avoiding the Medium Term Budget-Based Objectives (MTO). Nevertheless, it is possible to say that in the last few years, EU budget deficits have been in a more positive trend than the 2009 global crisis period deficits. Indeed, in 2009, structural deficits as a proportion of GDP emerged at $4.5 \%$, but in 2018 it fell to $0.7 \%$.

In the light of all these, it is seen that as a result effect of the deviations from the financial borrowings related to the functional effectiveness of budget applications in the Euro Area, this fact expresses a concrete structure with structural institutional imbalances. In other words, the impact of financial deviations in the Euro Area, especially in the aftermath of the 2009 crisis, has shown negative impacts together with meaningful dramatic increases in the new member countries as more stunning structural deviations (Craig, 2014: 34). However, at this point, the totalgeneral deviations in the Euro Area are smaller and homogeneous compared to the structural deviations at the country level. In Figure 3, it is possible to see the structural deviations in the Euro Area and the countries in this field below:

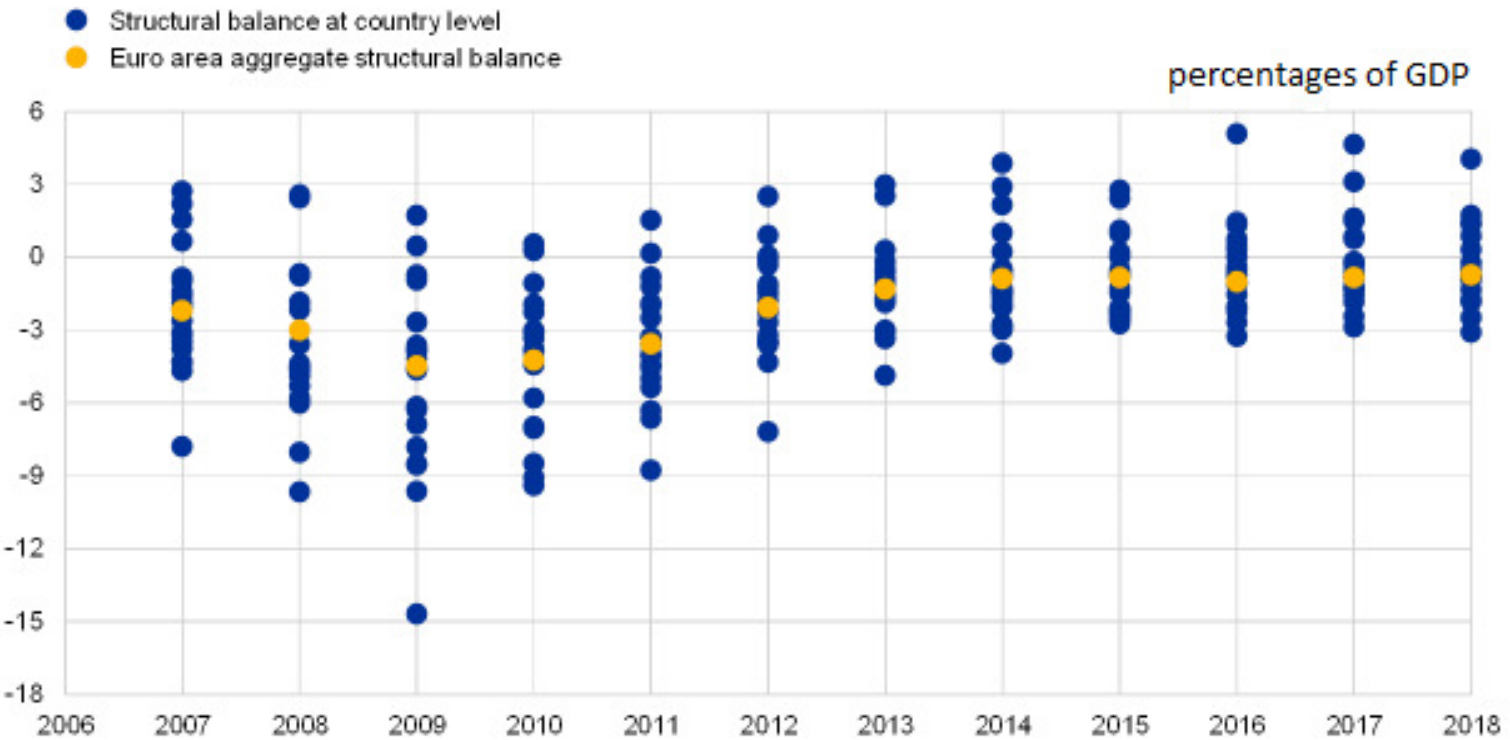

Source: European Central Bank (2019-a), Fiscal Rules in the Euro Area and Lessons from Other Monetary Union, https://www.ecb.europa.eu/pub/economic-bulletin/articles/2019/html/ecb.ebart201903 02 e835720b96.en.html\#toc1(Accessed 19.07.2019).

Figure 3. The Structural Deviations Related to Budget Balances in Euro Area

As can be seen in Figure 3, it can be said that in the post-2009 years as a positive result structural deviations entered a more positive process there were reductions in debt limits as a ratio of GDP in countries in the Euro Area. Indeed, the average debt ratio of the member states, which was around $65 \%$ as a percentage of GDP in 2007 and reached $90 \%$ in $2009-2010$, was $94.2 \%$ in 2014 as a result of the expanding borrow content of up to. Therefore, these years are also the years in which the effectiveness of budget functions in the Euro Area is considerably weakened. But, the overall impact of the stringent fiscal policy rules and the functional effectiveness of the new budget instruments, which increased with the expanding scale of fiscal discipline, reduced the average debt-tobudget ratios in the Euro Area in 2018 to $86.9 \%$ as a percentage of GDP.

In this point, it should be emphasized that the budget-based structural deviations in the Euro Area, especially after the 2009 crisis the deviations related to each member country, were the subject of higher deviations. To put forth it more clearly, the countries in the Euro Area are Germany, Austria, Belgium, Estonia, Finland, France, the Netherlands, Ireland, Spain, Italy, Cyprus, Latvia, Lithuania, Luxembourg, Malta, Portugal, Slovakia, Slovenia and Greece. The structural deviations are higher in the United Kingdom, the Czech Republic, Denmark, Estonia, Sweden, Latvia, Lithuania, Hungary, Romania, Poland and Bulgaria, which are not Euro-using countries other than the Euro. In this context, it is understood that the functional effectiveness of a common budget policy is higher in the Euro Area and on the more balanced structural ground have moved. Therefore, the financial function of the new budget instruments has resulted in a significant equilibrium efficiency in the Euro Area, with a minimum 
deviation of only about $-3 \%$ of GDP, making the budgetary effectiveness of functional financial instruments more meaningful (European Central Bank, 2019-b).

\section{Conclusion}

The recent discussions of the EU budget's functional effectiveness in the Euro Area, especially after the 2009 crisis, has often raised the functional effectiveness of the EU budgetary financial instruments and has increased the examines of financial efficiency on the basis of the suitability of the new budget instruments to the EU's objectives. The effectiveness of the current budget instruments in achieving the budgetary impact in the Euro Area is meaningful with the functional level of the funds and mutual funds related to the structural balances within the EU and these concerned reforms related to the recent structural adjustment qualifications have been developed in this direction. It is observed that the features of EU financial budget instruments have recently differentiated from classical financial budget instruments due to EU presented targets.

In particular, it appears that the budget's need for funding from member countries to meet the increasing funding needs and the need for even higher debt limits increased the range of target financial functions targeted by the EU budget. This phenomenon, which emerged as a result of global financial developments, can be considered in two main categories within the framework of target budget expectations and budget-based financial functions. The first one is aimed at achieving the desired level of capital mobilization, as well as the defence and continental security of the EU budget balance, common energy policies and the common transport trend among EU member states. Within the framework of these objectives, it is seen that reform support programs are the primary objective. The second is to create a global fiscal discipline trend for the EU budget in establishing a common budget fiscal discipline. The establishment of budget-based revenue and expenditure policies to ensure fiscal discipline for the EU also reveals the content level of current financial instruments in the provision of functional effectiveness in the Euro Area. In addition, it is seen that higher functional budgetary deviations have been experienced in the recent periods where program budget implementations frequently raise higher limit borrowings and is needed more established basic corporate financial locations. On the other hand, although a common budget application in the Euro Area directly affects the countries that use the Euro in terms of budget participation funds, but also this formation has affected on the other EU member countries in which non-using of the Euro Currency. This is because, this financial phenomenon is directly related to the basis of mutual investment funds that will ensure more meaningful the structural balances for all EU countries. At this point, the functional effectiveness of financial instruments prioritizes a process which has put forth lower efficiency for EU countries except the Euro Area as currency unit, especially in times of crisis. In other words, the functional effectiveness of a common EU budget reveals a higher deviation of structural efficiency in countries outside the Euro Area.

\section{References}

Alexander, K. (2010), Corporate Governance and Banking Regulation, Working Paper 17, Cambridge: Cambridge Endowment for Research in Finance, June 2004.

Barbier-Gauchard, A., Ferrer, J. N., Katarivas, M., \& Mathis, A. (2014), EU Budget and National Budgets: Facts, Figures and Impact, Brussels: Directorate General for Internal Policies Policy Department D: Budgetary Affairs, 2014.

Broin, P. (2012), The Euro Crisis: The fiscal Treaty - an Initial Analysis, Working Paper No. 5, Dublin: The Institute of International and European Affairs, 2012.

Council of The European Union (2017), Specifications on The Implementation of The Stability and Growth Pact and Guidelines on The Format and Content of Stability and Convergence Programmes, 9344/17, ECOFIN 423, UEM 170, Brussels: Council of The European Union 2017.

Craig, P. (2014), "Economic governance and the euro crisis: constitutional architecture and constitutional implications", in The Constitutionalization of European Budgetary Constraints, M. Adams, F. Fabbrini F. and P. Larouche (eds.), Oxford: Hart Publishing, 19-40.

Dang, T.T., Antolin, P. \& Oxley, H. (2001), Fiscal Implications of Ageing: Projections and Age-Related Spending, OECD Economics Department Working Papers No. 305, Paris: OECD Economics Department.

Dias, C., Hochhalter, L. Macchi, S. \& Zoppè, A. (2019), "Recommendations on the Economic Policy of the Euro Area under the European Semester - January 2019", In Depth Analysis, Brussels: European Parliament Directorate-General for Internal Policies, Economic Governance Support Unit (EGOV), PE 624.429-17 January 2019.

Downes, R., Moretti, D., \& Nicol, S. (2017), Budgeting and Performance in the European Union: A Review by The OECD in The Context of EU Budget Focused on Results, OECD Journal on Budgeting Volume 2017/1, OECD 2017.

Druel, E., Chrzanowski,, P., Pollock, R. \& Gray, J. (2015), Where Does Europe's Money Go? A Guide to EU Budget Data Sources, EU Budget Guide by Open Knowledge, July 2015.

European Central Bank (2019-a), Fiscal Rules in the Euro Area and Lessons from Other Monetary Union, 
https://www.ecb.europa.eu/pub/economicbulletin/articles/2019/html/ecb.ebart201903 02 e835720b96.en.html\#toc1 (Accessed 19.07.2019).

European Central Bank (2019-b), The Euro Area: Current Status and The Monetary Policy Stance, Remarks by Luis de Guindos at Deusto Business School: Recent Economic Developments, Madrid, 11 February 2019, Frankfurt am Main: European Central Bank, 2019, https://www.ecb.europa.eu/press/key/date/2019/html/ecb.sp190211 6b70b3a599.en.html_ (Accessed 28.07.2019).

European Commission (2017), Draft EU Budget 2018 - Questions and Answers, Brussels: European Commission Directorate, 30 May 2017.

European Commission (2018), EU Budget for The Future, SWD (2018) 171, Brussels: European Commission Directorate, 2.5.2018, COM (2018).

European Commission (2018), "Budgetary Instruments for a Strong and Stable Euro Area within The Union Framework", Deepening Europe's Economic and Monetary Union, Brussels: European Commission Directorate, December 2018.

European Commission (2019), Post-2020 MFF Orientations for Cohesion Policy, Brussels: European Commission Directorate, 2019.

European Parliament (2010), Creating Greater Synergy Between European and National Budgets, Brussels: Directorate-General for Internal Policies-Policy Department of Budgetary Affair, Study, 2010.

Fabbrini, F. (2019), A Fiscal Capacity for the Eurozone: Constitutional Perspectives, European Parliament Policy Department, Brussels: Directorate General for Internal Policies of the Union European Parliament Policy Department for Citizens' Rights and Constitutional Affairs, 2019.

Ferrera, M. (2018), "The European Social Union: How to Piece It Together", in Social Policy in The European Union: State of Play 2018, Bart Vanhercke, Dalila Ghailani and Sebastiano Sabato (eds.), Brussels: European Trade Union Institute (ETUI) and European Social Observatory (OSE), 2018.

Hepiertz, M. \& Verdun, A. (2010), Ruling Europe: The Politics of The Stability and Growth Pact, Cambridge: Cambridge University Press, 2010.

HM Treasury (2018), European Union Finances 2017: Statement On The 2017 EU Budget and Measures to Counter Fraud and Financial Mismanagement, Presented to Parliament by The Chief Secretary to the Treasury by Command of Her Majesty-Cm 9576, London: the UK by The APS Group on Behalf of The Controller of Her Majesty's Stationery Office, 2018.

Isaac, L., Lawal, M. \& Okoli, T. (2015), "A Systematic Review of Budgeting and Budgetary Control in Government Owned Organizations", Research Journal of Finance and Accounting, 6(6), 1-10.

Mortensen, J. (2013), Economic Policy Coordination in The Economic and Monetary Union From Maastricht via The SGP to The Fiscal Pact, Ceps Working Document: Thinking Ahead for Europe, No:381, August 2013, Warsaw: Ceps Working Document, 2013.

OECD (2018), OECD Economic Surveys: Euro Area, OECD, June 2018

Shhick, A. (2003), The Role of Fiscal Rules in Budgeting, OECD Journal on Budgeting, Vol. - No. 3, OECD 2003. Vooren, B. V. (2010), A Legal-Institutional Perspective on The European External Action Service, CLEER Working Papers 2010/7, Hague-Netherland: Centre for The Law of EU External Relations, 2010.

Wescott, C. G. (2008), Background Paper to Public Sector Reform: What Works and Why? an IEG Evaluation of World Bank Support, IEG Working Paper 2008, Washington, D.C.: The World Bank Support for Public Financial Management: Conceptual Roots and Evidence of Impact, September 15, 2008. 